\title{
PENERAPAN MIND MAPPING DALAM UPAYA PENINGKATAN KETERAMPILAN PROSES SAINS MAHASISWA PADA MATAKULIAH MIKROBIOLOGI MELALUI LESSON STUDY
}

\author{
Muh. Waskito Ardhi \\ Pendidikan Biologi, Fakultas PMIPA, IKIP PGRI MADIUN \\ waskitoardhi@gmail.co.id
}

\begin{abstract}
Lesson study is a model of professional development of educators through collaborative research and continuous learning based on the principles of mutual kolegalitas and learning to build community study. Lesson study can be implemented at various levels of education, including college. The level of implementation of the Lesson study done is learning plan, implementation of learning, and reflection. Lesson study cycle is done 4 times with the topic Fungi, Sterilization, Media Bacteria and Isolation, and Environmental Microbiology. Lesson study results showed an increase in the quality of learning that is Microbiology Subjects with variations learning methods, learning strategies, media variations, and how to evaluate, especially in the use of Mind Mapping. Lesson study is ongoing implementation will accelerate the implementation of professional development learning. Increased professionalism of lecturers will be followed by an increase effectiveness of learning and teaching and will indirectly have an impact on improving the quality of education at large.
\end{abstract}

Keywords : Mind Mapping, Process Science, Microbiology .

\section{PENDAHULUAN}

Mata kuliah Mikrobiologi merupakan salah satu mata kuliah yang perlu di pahami oleh mahasiswa terkait dengan pemahaman tentang mikroorganisme. Di dalam matakuliah mikrobiologi diharapkan mahasiswa memahami asal usul mikrobia, dunia mikroba prokariotik, dan eukariotik, aplikasi serta peranannya bagi manusia.

Dilihat dari karakteristik materi didalam perkuliahan mikrobiologi maka dosen harus membuat suatu strategi, metode dan media dalam pembelajaran yang membuat mahasiswa mengembangkan kemampuannya untuk belajar secara mandiri melalui metode dan pendekatan yang inovatif.

Pembelajaran yang selama ini terjadi adalah dengan pembelajaran yang bersifat Lecturer centered yaitu pembelajaran yang berpusat pada dosen dan mahasiswa cenderung pasif didalam perkuliahan serta mahasiswa cenderung tidak mau mencari bahan belajar sehingga hanya mengharapkan materi perkuliahan dari dosennya saja. Proses perkuliahan belum mencerminkan proses pembelajaran sains yang sebenarnya. Mahasiswa cenderung mengejar nilai kognitif saja tanpa memperdulikan aspek yang juga sangat penting yaitu psikomotorik dan afektif. Disamping itu penilaian dosen juga bertumpu pada penilaian kognitif belum secara optimal mengeksprolarasi penilaian psikomotorik dan afektif.

Pembelajaran

Mikrobiologi didalam kelas semestinya diajarkan sesuai karakteristik biologi khususnya Mikrobiologi yaitu pembelajaran yang menekankan pada keterampilan proses sains dari mahasiswa, pembelajaran yang tidak menekankan pada satu aspek kognitif (minds on) saja tetapi juga aspek psikomotorik (hands on) serta sikap ilmiah (hearts on).

Menurut Pudyo (1999), menyatakan bahwa keterampilan proses sains dibedakan menjadi keterampilan proses dasar dan keterampilan proses terintegrasi. Keterampilan proses sains dasar meliputi: observasi, klasifikasi, pengukuran, komunikasi, menyimpulkan, prediksi, penggunaan hubungan tempat dan waktu, 
penggunaan angka, dan identifikasi variable. Sedangkan keterampilan proses sains terintegrasi meliputi: penyusunan hipotesis, pengontrolan, variable, investigasi, pendefinisian operasional, dan eksperimentasi.

Hal ini relevan dengan pendapat Rustaman (2002), bahwa keterampilan proses sains adalah keterampilan yang diperoleh dari latihan kemampuankemampuan mental, fisik, dan sosial yang mendasar sebagai penggerak kemampuan yang lebih tinggi. Pendekatan dalam keterampilan proses dijabarkan dalam kegiatan belajar mengajar memperhatikan pengembangan pengetahuan sikap, nilai serta keterampilan. Keterampilan proses bertujuan untuk meningkatkan kemampuan anak didik menyadari, memahami dan menguasai rangkaian bentuk kegiatan yang berhubungan dengan hasil belajar yang telah dicapai anak didik. Rangkaian bentuk kegiatan yang dimaksud adalah kegiatan mengamati, menggolongkan, menafsirkan, meramalkan, menerapkan, merencanakan penelitian, dan mengkomunikasikan.

Hasil pengamatan menunjukkan bahwa dosen pada saat pembelajaran kurang memberikan perkuliahan kurang variatif baik strategi, pendekatan, dan metode yang menyebabkan mahasiswa kurang bergairah dan dosen didalam memberikan perkuliahan belum mencermikan perkuliahan atau pembelajaran yang sesuai dengan proses pembelajaran biologi baik hakikat maupun karakteristik dan kurang menekankan pada ketrampilan proses sains.

Mind mapping adalah alternatif pemikiran keseluruhan otak terhadap pemikiran linear. Mind mapping menggapai ke segala arah dan menangkap berbagai pikiran dari segala sudut (Michael michalko, dalam Buzan (2008). Dengan kata lain mind mapping adalah cara mencatat yang kreatif, efektif, dan memetakan pikiran-pikiran kita, secara menarik, mudah dan berdaya guna serta mind mapping adalah cara termudah untuk menempatkan informasi ke dalam otak dan mengambil informasi itu ketika dibutuhkan. Mind mapping akan memberikan pandangan menyeluruh tentang pokok masalah atau area yang luas, mengumpulkan sejumlah besar data dari suatu permalasahan, mendorong mahasiswa memecahkan masalah dengan membiarkan mahasiwa dengan terobosan yang kreatif serta membuat mahasiswa senang melihat, membaca, mencerna dan mengingat bahan ajar atau materi pembelajaran dan akhirnya kemampuan keterampilan proses sains mahasiswa dapat meningkat.

Oleh karena itu perlu adanya pengembangan model pembelajaran. Pada kesempatan ini, salah satu model pembelajaran yang tepat adalah model lesson study melalui teknik Mind mapping. Pendekatan lesson study merupakan sebuah model pembinaan profesi pendidik melalui pengkajian pembelajaran secara kolaboratif menawarkan alternatif-alternatif untuk membangun dan memperbaiki iklim proses pembelajaran agar lebih berkualitas. Dengan model lesson study ini, setiap proses pembelajaran akan selalu ada pengamatan dan refleksi. Dengan pelaksanaan kegiatan Lesson Study pada mata kuliah Mikrobiologi diharapkan dapat mendorong terciptanya iklim belajar yang lebih kondusif, sehingga dapat meningkatkan kemampuan belajar mahasiswa dan dapat meningkatkan keterampilan proses sains mahasiswa.

Tujuan didalam penelitian ini adalah untuk meningkatkan keterampilan proses sains mahasiswa pada Mata Kuliah Mikrobiologi melalui teknik Mind Mapping dengan menggunakan model lesson Study pada mahasiswa Program Studi Pendidikan Biologi FP MIPA IKIP PGRI MADIUN.

\section{METODE PENELITIAN}

Pendekatan penelitian ini adalah penelitian tindakan (action research). Menurut Hardjodipuro (1997: 7) penelitian tindakan (action research) adalah perbaikan atau peningkatan mutu, baik secara mikro maupun makro, karena penelitian ini 
bertujuan untuk meningkatkan pembelajaran dengan memberikan tindakan alternatif dengan model lesson study. Tindakan alternatif tersebut dibuat oleh peneliti, yang kemudian diujicobakan kepada mahasiswa dalam pembelajaran. Penelitian tindakan yang dilakukan secara kolaboratif dan partisipatif. Kolaboratif dan partisipatif artinya peneliti (dosen model) bekerjasama dengan dosen lain untuk merancang, mengamati dan melakukan refleksi terhadap pembelajaran yang dilakukan. Tindakan yang direncanakan berupa penerapan model pembelajaran kooperatif dan pemanfaatan handout. Dalam penelitian tindakan ini, peneliti menggunakan model yang dikembangkan oleh Stephen Kemmis dan Robin McTaggart yang terdiri dari beberapa siklus. Adapun setiap siklusnya terdapat 3 tahapan yaitu perencanaan (plan), pelaksanaan (act) dan observasi (observe), dan refleksi (reflect).

Teknik pengumpulan data pada penelitian ini adalah obsevasi. Teknik ini digunakan untuk memperoleh data tentang hasil penelitian, selanjutnya dari hasil penelitian tersebut dipadukan untuk mengambil kesimpulan dari penelitian ini.

Observasi dilaksanakan pada saat proses pembelajaran berlangsung untuk mengamati subyek penelitian atas perlakuan tindakan. Mencatat secara cermat semua kesulitan mahasiswa selama proses tindakan. Data yang diperoleh dari penelitian ini adalah data kualitatif. Analisis data dilakukan menurut karakteristik masing-masing data yang terkumpul diklasifikasikan dan dikategorisasikan secara sistematik dan menurut karakteristiknya. Temuan ini akan digunakan untuk melaksanakan tindakan selanjutnya.

\section{HASIL DAN PEMBAHASAN}

Penerapan strategi pembelajaran pada matakuliah Mikrobiologi Mind Mapping ini melalui Lesson Study pada siklus pertama sampai siklus keempat. Setiap tahapan/siklus mengacu pada tahapan Lesson study yaitu tahap perencanaan, tahap pelaksanaan/pengamatan dan tahap refleksi. Dengan penerapan strategi Mind Mapingg melalui Lesson Study diharapkan peneliti dapat memahami kekurangan, kelemahan karena mendapat pengamatan dan masukan dari observer sehingga akan berdampak pada perbaikan kualitas pembelajaran berikutnya.

\section{Kegiatan dan Hasil Lesson Study I}

Tahap perencanaan I (plan I) ini dosen model bersama team dosen rumpun hewan melakukan perencanaan pembelajaran yang meliputi Silabus, RPP, Hand Out, Metode dan Strategi. Materi pembelajarannya adalah fungi (jamur). Metode pembelajaran yang akan digunakan adalah Praktikum, pengamatan dan Diskusi kelompok. Strategi pembelajaran dengan menggunakan Mind Mapping. Media Pembelajaran adalah dengan menggunakan media asli yaitu jamur pada tempe, jamur pada roti, powerpoint tentang materi jamur.

Tahap pelaksanaan (do I) dilaksanakan pada hari Selasa, 19 April 2011. Pada tahap ini merupakan aplikasi dari hasil planning bersama team dosen yang tercover dalam RPP. Sedangkan observer bertindak sebagai pengamat saat proses pembelajaran dikelas berlangsung.

Hasil pelaksanaan pembelajaran ( $d o$ I) yang telah dilakukan ada beberapa masukan dari observer (pengamat) sebagai berikut: 1) Apersepsi yang disampaikan terlalu panjang dengan penanyangan slide, sehingga mahasiswa belum sepenuhnya menjawab pertanyaan-pertanyaan yang diajukan oleh dosen model. Apersepsi yang diberikan dengan bahasa inggris membat mahasiswa menjadi konsentrasi. 2) Hampir semua mahasiswa sudah dapat belajar, tapi ada 1 mahasiswa (A) yang tidak melakukan praktik tapi bisa membuat Mind Mapping. 3) Penggunaan mikroskop yang terbatas, hasil pengamatan tidak sesuai dengan apa yang diharapkan, sehingga mahasiswa kurang dapat menganalisis sesuai dengan peta pikirannya. Tetapi pada setiap diskusi, semua mahasiswa di tiap kelompok saling 
mendiskusikan hasil pengamatannya. 4) Dosen model memberi/mendampingi mahasiswa setiap kelompok dalam pembuatan Mind mapping. 5) Di dalam pengamatan jamur mahasiswa belum sepenuhnya paham dari apa yang akan diamati. 6) Ada beberapa kelompok yang sulit menggunakan mikroskop terutama dalam mencari cahaya. 7) Sebaiknya dosen menggunakan mikroskop dari cahaya listrik dalam pengamatan jamur (fungi).

Keterampilan proses sains yang diukur adalah keterampilan proses sains dasar yaitu observasi dan ketrampilan proses sains terintegral eksperimen. Dari hasil pelaksanaan pertemuan I diperoleh hasil sebagai berikut. Hasil pengamatan keterampilan proses sains mahasiswa adalah : 1) Rata-rata pencapaian keterampilan proses sains dasar observasi (mengamati) yang diperoleh mahasiswa dalam setiap kelompok (4 mahasiswa) adalah rata-rata 2 dari 4 indikator kps observasi (rata-rata 50\%). 2) Rata-rata pencapaian keterampilan proses sains terintegral eksperimen dari mahasiswa dalam setiap kelompok adalah rata-rata 2 dari 4 indikator kps eskperimen (rata-rata $50 \%)$.

Tingkat ketercapaian indikator keterampilan proses sains baik dasar maupun terintegral juga didukung berdasarkan observasi dari dosen pengamat (observer) yang diperoleh selama pengamatan pada saat Do diantaranya sebagai berikut : 1) Hampir semua mahasiswa sudah dapat belajar, tapi ada 1 mahasiswa (A) yang tidak melakukan praktik tapi bisa membuat Mind Mapping. 2) Penggunaan mikroskop yang terbatas, hasil pengamatan tidak sesuai dengan apa yang diharapkan, sehingga mahasiswa kurang dapat menganalisis sesuai dengan peta pikirannya. Tetapi pada setiap diskusi, semua mahasiswa ditiap kelompok saling mendiskusikan hasil pengamatannya.

3) pengamatan jamur mahasiswa belum sepenuhnya paham dari apa yang akan diamati. 4) Ada beberapa kelompok yang sulit menggunakan mikroskop terutama dalam mencari cahaya.

Solusi yang muncul dalam refleksi adalah 1) Penggunaan Mind Mapping harus didampingi karena mahasiswa belum pernah menggunakannnya. 2) Penilaian Ketrampilan Proses Sains untuk indicator sebaiknya diperjelas. 3) Sebaiknya dosen menggunakan mikroskop dari cahaya listrik dalam pengamatan jamur (fungi). 3) Penggunaan bahasa inggris dalam apersepsi membuat mahasiswa termotivasi, sebaiknya penggunaan terus diterapkan dengan bahasa yang mudah dipahami mahasiswa.

\section{Kegiatan dan Hasil Lesson Study II}

Tahap perencanaan II ini dosen model bersama team dosen rumpun hewan melakukan perencanaan pembelajaran yang meliputi Silabus, RPP, Hand Out, Metode dan Strategi. Materi Pembelajarannya adalah sterilisasi alat sebagai usaha awal mengisolasi mikroorganisme. Metode pembelajaran yang akan digunakan adalah Mind Mapping, Praktikum, dan Demonstrasi. Strategi pembelajaran dengan menggunakan Mind Mapping. Media Pembelajaran adalah dengan menggunakan Powerpoint serta penggunaan alat dalam praktikum.

Tahap pelaksanaan (do II) dengan materi sterilisasi Alat. Pada tahap ini merupakan aplikasi dari hasil planning bersama team dosen yang tercover dalam RPP. Sedangkan observer bertindak sebagai pengamat saat proses pembelajaran dikelas berlangsung.

Tahapan Refleksi (See II), hasil pelaksanaan pembelajaran (Do) yang telah dilakukan ada beberapa masukan dari observer (pengamat) sebagai berikut : 1) Belum semua mahasiswa terfokus pada materi yang disampaikan dosen beberapa duduk, diam, melihat tanpa berperan dalam sterilisasi. 2) Mahasiswa dengan inisial (H), (HI) belum fokus dan sering tidak memperhatikan penjelasan dosen. 3) Karena mahasiswa merasa tidak terlalu penting sehingga tidak tahu pemanfaatannya. 4) Mahasiswa belum 
paham nama alat-alat. 5) Usaha dosen mendorong mahasiwa untuk aktif dengan membuat Mind Mapping sehingga apa yang diperoleh mahasiswa dapat dipahami. 6) Penggunaan Main Mapping untuk mahasiswa belum bisa. 7) Belum semua mahasiswa dapat belajar dengan baik, pada saat melakukan sterilisasi, penggunaan atau metode sterilisasi belum semua dipahami, sehingga beberapa mahasiswa hanya diam saja, tidak melakukan (pembungkusan, penyumbatan alat dengan kapas, memasukkan ke inkubator). 8) Usaha dosen adalah dengan berkeliling ke tiap kelompok, sambil memberi penjelasan.

Keterampilan proses sains yang diukur sama dengan pertemuan I yaitu observasi untuk keterampilan proses sains dasar dan eksperimen untuk keterampilan proses sains terintegral. Hasil pengamatan keterampilan proses sains mahasiswa sebagai berikut: 1) Rata-rata tingkat ketercapaian ketrampilan proses sains dasar observasi (mengamati) yang diperoleh mahasiswa dalam setiap kelompok belum mengalami peningkatan dibandingkan pertemuan I yaitu rata-rata 2 (rata-rata $50 \%$ ). 2) Rata-rata tingkat ketercapaian ketrampilan proses sains terintegral eksperimen dari mahasiswa dalam setiap kelompok belum mengalami peningkatan dari pertemuan I yaitu 2 (rata-rata $50 \%$ ).

Tingkat pencapaian indikator yang mengalami peningkatan didukung pula berdasarkan hasil observasi yang dilakukan pengamat diperoleh hasil sebagai berikut : 1) Hampir semua mahasiswa sudah terfokus pada pengamatan gambar bakteri dengan menggunakan mikroskop. 2) Keterbatasan mikroskop masih menjadi kendala tetapi usaha dosen untuk memberikan waktu bergantian dapat mengurangi mahasiswa pasif. 3) Usaha dosen mendorong mahasiwa untuk aktif dengan membuat Mind Mapping dan peta konsep sehingga apa yang diperoleh mahasiswa dapat dipahami. 4) Penggunaan Mind Mapping untuk mahasiswa mengalami peningkatan. 5) Belum semua mahasiswa mengikuti dari cara kerja yang telah diberikan dosen, mengingat jumlah alat yang terbatas. 6) Usaha dosen adalah dengan berkeliling ke tiap kelompok, sambil memberi penjelasan. 7) Dosen memberikan pengertian bahwa pendapat kelompok berbeda-beda tapi memberikan kontribusi yang satu konsep.

Solusi yang diperoleh dari dosen pengamat (observer) : 1) Penggunaan Mind Mapping lebih ditekankan agar ketercapain indicator pembelajaran tercapai dan indicator pencapaian ketrampilan proses sains tercapai. 2) Peralatan untuk pengamatan bakteri sebaiknya diratakan atau di gilir mengingat jumlahnya terbatas. 3) Seharusnya tiap mahasiswa diberi kesempatan untuk menggunakan peralatan terutama mikroskop meskipun jumlahnya terbatas. 4) Keterampilan proses sains bisa ditambahkan, tidak hanya 2 aspek KPS yang diamati.

\section{Kegiatan dan Hasil Lesson Study III}

Tahap perencanaan III ini dosen model bersama team dosen rumpun hewan melakukan perencanaan pembelajaran yang meliputi Silabus, RPP, Hand Out, Metode dan Strategi. Materi Pembelajarannya adalah pembuatan media dalam usaha menumbuhkan mikroorganisme. metode pembelajaran yang akan digunakan adalah Active leaning, Praktikum, dan Demonstrasi. Media Pembelajaran adalah dengan menggunakan Powerpoint serta penggunaan alat dalam praktikum.

Tahap pelaksanaan (do III) dengan materi pembuatan media dan isolasi bakteri. Pada tahap ini merupakan aplikasi dari hasil planning bersama team dosen yang tercover dalam RPP. Dalam pelaksanaan (do), observer bertindak sebagai pengamat saat proses pembelajaran dikelas berlangsung.

Hasil pelaksanaan pembelajaran (do) yang telah dilakukan ada beberapa masukan dari observer (pengamat) sebagai berikut : 1) Aktivitas mahasiswa pada saat awal kegiatan sangat antusias tetapi pada saat menunggu merebus bahan dalam pembuatan media, mereka banyak yang diam, sebaiknya kegiatan dilakukan tiap kelompok. 2) Ada sebagian mahasiswa yang tidak mengikuti perkuliahan dengan 
baik. 3) Kegiatan pembelajaran terpusat pada kelompok depan, tidak semua kelompok diberi bahan. 4) Tidak semua mahasiswa. Ada sebagian mahasiswa (P), $(\mathrm{M}),(\mathrm{K}),(\mathrm{P})$ yang bicara sendiri atau duduk diam tanpa memperhatikan penjelasan dosen. 5) Tidak semua kelompok aktif karena berjubel-jubel.

Di dalam pertemuan ketiga ini materi pembelajarannya adalah tentang pembuatan media dalam usaha menumbuhkan mikroorganisme pengamatan meliputi bentuk bakteri, warna dan pola penataan bakteri. Dalam perencanaan ini metode pembelajaran yang akan digunakan adalah Praktikum, dan Demonstrasi.

Keterampilan proses sains yang diukur sama dengan pertemuan III yaitu observasi untuk keterampilan proses sains dasar dan eksperimen untuk keterampilan proses sains terintegral. Hasil pengamatan keterampilan proses sains mahasiswa sebagai berikut: 1) Rata-rata tingkat ketercapaian ketrampilan proses sains dasar observasi (mengamati) yang diperoleh mahasiswa dalam setiap kelompok mengalami peningkatan dibandingkan pertemuan III yaitu rata-rata 3 (rata-rata 75\%). 2) Rata-rata tingkat ketercapaian ketrampilan proses sains terintegral eksperimen dari mahasiswa dalam setiap kelompok sama dengan dari pertemuan III yaitu 3 (rata-rata $75 \%$ ).

\section{Kegiatan dan Hasil Lesson Study IV}

Tahap perencanaan IV ini dosen model bersama team dosen rumpun hewan melakukan perencanaan pembelajaran yang meliputi Silabus, RPP, Hand Out, Metode dan Strategi. Materi Pembelajarannya adalah mikrobiologi lingkungan yang meliputi air, udara, tanah, pangan. Perencanaan ini metode pembelajaran yang akan digunakan adalah presentasi setiap kelompok dengan menggunakan Mind Mapping. Dosen melakukan konfirmasi dari presentasi yang dilakukan oleh setiap kelompok.

Tahap pelaksanaan (do) / Open Lesson yang ke IVdiikuti dari dosen Program
Studi Pendidikan Biologi, Fisika dan Matematika sekaligus menjadi pengamat (observer).

Hasil pelaksanaan pembelajaran (Do) yang telah dilakukan ada beberapa masukan dari observer (pengamat) di tahapan refleksi (See) sebagai berikut :1) Belum semua mahasiswa tampil. Masih ada kesalahan dalam menjawab pertanyaan-pertanyaa yang tampil. Presentasi atau membawakan makalah saat menerangkan kurang jelas. 2) Kelompok yang tampil ke 2 dan ke 3 ada anggota yang duduk-duduk paling depan dan ada yang ngobrol sendiri. 3) Proses pembelajaran secra kelompok/berdiskusi hasilnya lebih baik dari pada pembelajaran secara individu. 4) Sebagian mahasiswa tidak dapat belajar dengan baik karena media yang digunakan tidak efektif. Apalagi pada kelompok Air tidak menguasai materi yang telah diberikan dosen. 5) Dosen sudah mendorong keaktifan mahasiswa namun hanya sedikit mahasiswa yang bisa aktif. 6) Kegiatan poembelajaran pada hari ini secara umum sudah berjalan dengan baik, namun karena mahasiswa kurang belajar satu sama lain sehingga kegiatan diskusi tidak bisa berjalan dengan baik. 6) Belum semua mahasiswa benar-benar belajar, tetapi sebagian besar sudah mengikuti dengan baik $90 \%$ dan $10 \%$ tidak aktif. 7) Usaha dosen dalam mendorong mahasiswa dengan memberikan pertanyaan untuk memancing pengetahuan mahasiswa akan tetapi belum semuanya berhasil. 8) Sebaiknya semua kelompok diberikan tugas untuk membuat makalah tentang semua topic yang akan dipresentasikan, walaupun pada saat presentasi setiap kelompok tetap focus pada topiknya masing-masing. 9) Dalam pembelajaran dengan menggunakan metode diskusi/presentasi sebaiknya media yang dipakai untuk penyampaian materi/makalah dikemas dalam bentuk yang lebih praktis/efisiesn dan menarik semisal dengan menggunakan powerpoint dan animasi yang diharapkan dapat menarik perhatian dan antusiasme peserta. 10) Mahasiswa hanya belajar pada topik yang menjadi bagian 
kelompoknya, sebaiknya dosen sering mengontrol mahasiswa yang tidak presentasi agar benar-benar memperhatikan kelompok penyaji. 11) Pada tahap do belum sesuai dari rencana yang telah dituliskan pada RPP terutama pembuatan Mind Mapping dari setiap kelompok. Ada beberapa kelompok yang membuat Mind Mapping tidak sesuai dengan konsep Mind Mapping, jadi sebagian belum sesuai dengan apa yang telah di planing.

Keterampilan proses sains yang diukur sama dengan pertemuan III yaitu observasi untuk keterampilan proses sains dasar dan eksperimen untuk keterampilan proses sains terintegral. Hasil pengamatan keterampilan proses sains mahasiswa sebagai berikut: 1) Rata-rata tingkat ketercapaian ketrampilan proses sains dasar observasi (mengamati) yang diperoleh mahasiswa dalam setiap kelompok sama dibandingkan pertemuan III yaitu rata-rata 3 (rata-rata 75\%). 2) Ratarata tingkat ketercapaian ketrampilan proses sains terintegral eksperimen dari mahasiswa dalam setiap kelompok sama dengan dari pertemuan III yaitu 3 (ratarata $75 \%$ ).

\section{SIMPULAN}

Berdasarkan hasil pembahasan penerapan strategi pembelajaran melalui Lesson Study yang telah dilakukan dapat disimpulkan: 1) Tahapan implementasi strategi pembelajaran dalam mikrobiologi melalui Lesson Study dilakukan dalam 3 tahap yaitu Perencanaan (Plan), Pelaksanaan (DO) dan Refleksi (See). 2) Implementasi strategi pembelajaran melalui Lesson Study membantu meningkatkan kemampuan dosen dalam melakukan pembelajaran di kelas. 3) Bertambahnya pengetahuan bagi dosen tentang metode, strategi, evaluasi, media dalam meningkatkan kemampuan dalam mengajar dan menguasai di kelas. 4) Adanya Lesson study dosen dapat mengetahui kekurangan selama dalam proses pembelajaran dan dapat mengetahui bagaimana solusi untuk mengatasi permasalahan-permasahan yang dihadapi pada saat proses pembelajaran. 5) Diharapkan para dosen khususnya program studi pendidikan biologi menerapkan suatu metode, strategi, model, pendekatan pembelajaran dengan melalui Lesson Study sehingga dapat mengetahui kekurangan dan mengetahui solusi yang dapat membantunya dalam proses pembelajaran. 6) Adanya Lesson Study diharapkan profesionalisme dosen semakin meingkat.

\section{DAFTAR PUSTAKA}

Anna Rahmawati, dkk. 2010. Implementasi Lesson Study dalam Kuliah Mikrobiologi Jurdik Biologi FMIPA UNY.

Buzan, Tony. 2008. Buku Pintar Mind Map. Jakarta : PT Gramedia Pustaka Utama.

Hendayana, dkk. 2007. Lesson study suatu strategi untuk meningkatakan keprofesionalan pendidik (Pengalaman IMSTEP-JICA). UPI Press. Bandung

Santyasa. 2009. Seminar Implementasi Lesson Study dalam Pembelajaran bagi Guru-Guru TK, Sekolah Dasar, dan Sekolah Menengah Pertama di Kecamatan Nusa Penida, Makalah Seminar.

Pelita. 2009b. Panduan untuk Lesson study berbasis MGMP dan Lesson study Sekolah. Depdiknas/Depag-JICA. Jakarta

Pudyo, Susanto, (1999). Strategi Pembelajaran Biologi Di Sekolah Menengah.Malang : Fak.MIPA Universitas Negeri Malang.

Rustaman, et al, 2010, Strategi Belajar Mengajar Biologi. FPMIPA UPI.

Sukirman. 2006. Peningkatan Profesionalan Guru Melalui Lesson Study. Makalah Disampaikan pada Diklat Lesson Study bagi Guru Berpretasi dan Pengurus MGMP MIPA SMP se-Indonesia Tengah: Yogyakarta: FMIPA UNY. - 2011. Implementasi Pendidikan Karakter Dalam Perkuliahan Melalui Lesson Study (Suatu Alternatif). Makalah Workshop dan Seminar Nasional UNY. 